\title{
Batch phenol biodegradation study and application of factorial experimental design
}

\author{
D. Hank", N. Saidani, A. Namane and A. Hellal \\ National Polytechnic School, Environmental Engineering Department, Laboratory of Sciences and Environmental Techniques, \\ 10 Avenue Hacen Badi, BP182 El Harrach (16200) Algiers. Algeria.
}

Received 30 December 2009; Revised 25 February 2010; Accepted 25 May 2010

\begin{abstract}
A bacterium, Pseudomonas aeruginosa (ATTC27853), was investigated for its ability to grow and to degrade phenol as sole carbon source, in aerobic batch culture. The parameters which affect the substrate biodegradation such as the adaptation of bacteria to phenol, the temperature, and the nature of the bacteria were investigated. The results show that for a range of temperature of 30 to $40^{\circ} \mathrm{C}$, the best degradation of phenol for a concentration of $100 \mathrm{mg} / 1$ was observed at $30^{\circ} \mathrm{C}$. The regeneration of the bacterium which allows the reactivation of its enzymatic activity, shows that the degradation of $100 \mathrm{mg} / 1 \mathrm{of}$ substrate at $30^{\circ} \mathrm{C}$ required approximately 50 hours with revivified bacteria, while it only starts after 72 hours for those no revivified. Adapted to increasing concentrations, allows the bacteria to degrade a substrate concentration of about $400 \mathrm{mg} /$ 1 in less than 350 hours.

A second part was consisted in the determination of a substrate degradation model using the factorial experiment design, as a function of temperature $\left(30-40^{\circ} \mathrm{C}\right)$ and of the size of the inoculums $(260.88-521.76 \mathrm{mg} / 1)$. The results were analyzed statistically using the Student's t-test, analysis of variance, and F-test. The value of $\mathrm{R}^{2}(0.99872)$ and adjusted $\mathrm{R}^{2}(0.9962)$ close to 1.0, verifies the good correlation between the observed and the predicted values, and provides the excellent relationship between the independent variables (factors) and the response (the time of the phenol degradation). F-value found above 200 , indicates that the considered model is statistically significant.
\end{abstract}

Keywords: Biodegradation, Phenol, Pseudomonas aeruginosa, Factorial experimental design.

\section{Introduction}

Phenol and phenolic compounds are of general use in many industries such as polymeric resin production and oil refining. As a result, these compounds are commonly encountered in industrial effluents and surface water.

The low volatility of phenol and its affinity for water make oral consumption of contaminated water the greatest risk to humans [1].

To treat phenolic compounds, biological methods are preferable because this is economical, and there is a low possibility of the production of by-products. Many papers support the biological treatment of waste or ground water. The microorganisms used are usually aerobes which transform organic compounds to inorganic compounds $\left(\mathrm{CO}_{2}, \mathrm{H}_{2} \mathrm{O}\right)$ [1].

The objective of the present paper was to study the biodegradation process, considering simultaneous variations of the factors that could affect to it, and to build a mathematical model of the time of phenol degradation as a function of variables involved to find the experimental conditions in which the biodegradation

*E-mail address: hdalila74@yahoo.fr

ISSN: 1791-2377 (C) 2010 Kavala Institute of Technology. All rights reserved. process was efficient. For finding efficient conditions in experimentation we used the factorial experimental design.

The factorial experimental design methodology involves changing all variables from one experiment to the next. The reason for this is that variables can influence each other, and the ideal value for one of them can depend on the values of the others. This interaction between variables is a frequent phenomenon.

Many studies relating to biodegradation process have indicated the effect of the temperature, the $\mathrm{pH}$, the concentration of the effluent, the agitation, the aeration, and the size of bacteria on the treatment efficiency. However, few employ the experimental design method for evaluating the influence of the operation variables on these processes.

Usama et al. [2] studied the effect of inoculum size on phenol biodegradation using Acinetobacter sp., the authors concluded that increasing of the inoculum increased the rate of phenol biodegradation.

Si-Jing and Kai-Chee [3] studied the kinetics of phenol biodegradation by Pseudomonas putida, the relationship between cell growth rate and substrate consumption was established under several conditions, the authors proved that phenol concentration was 
an important factor on its biodegradation.

Agarry et al. [4] studied the effect of the temperature, the aeration, and the agitation on the degradation of phenol by Pseudomonas aeruginosa using response surface methodology, the optimum process conditions for maximizing phenol degradation was given at temperature $30.1^{\circ} \mathrm{C}$, aeration $3 \mathrm{vvm}$, and agitation $301 \mathrm{rpm}$.

Tao et al. [5] used the Box-Behnken center-united experimental design to determine the effects of glucose concentration, initial $\mathrm{pH}$, and culture temperature on omethoate degradation by Aspergillus niger, the optimum conditions were: $1.9 \%(\mathrm{w} / \mathrm{v})$ glucose, initial $\mathrm{pH} 6.21$, and culture temperature $32.64^{\circ} \mathrm{C}$.

\section{Experimental}

\subsection{Medium}

The mineral medium composed of the following components $(\mathrm{g} / \mathrm{l})$ [6]: $\mathrm{KH}_{2} \mathrm{PO}_{4}, 0.5 ; \mathrm{K}_{2} \mathrm{HPO}_{4}, 1.5 ; \mathrm{NaCl}, 0.5 ; \mathrm{Mg} \mathrm{SO} \mathrm{S}_{4} .7 \mathrm{H}_{2} \mathrm{O}, 0.5$; $\mathrm{NH}_{4} \mathrm{NO}_{3}, 1 ; \mathrm{FeSO}_{4} .7 \mathrm{H}_{2} \mathrm{O}, 0.01 ; \mathrm{CaCl}_{2} .2 \mathrm{H}_{2} \mathrm{O}, 0.01 ; \mathrm{NH}_{4} \mathrm{SO}_{4}, 0.5$.

All media (except phenol) was autoclaved at $120^{\circ} \mathrm{C}$ for 20 min for sterilization before using. Phenol was added to the medium with desired initial concentration.

After inoculation; by adding $10 \mathrm{ml}$ of Inoculum into 11 of medium, the flasks were capped with cotton plugs and placed in a shaker under aerobic conditions.

\subsection{Analytical methods}

Cell density was monitored spectrophotometrically by measuring the absorbance at a wavelength of $600 \mathrm{~nm}$ by using a Shimadzu ultraviolet spectrophotometer. The OD value was then converted to dry cell mass using a dry weight calibration curve.

The dry cell mass density $(\mathrm{mg} / \mathrm{l})$ was found to follow the regression equation: $\mathrm{X}(\mathrm{mg} / \mathrm{l})=434.8\left(\mathrm{OD}_{600}\right)$.

Phenol was analysed by photometric method using 4-aminoantipyrine as the colouring agent and measuring the absorbance at $510 \mathrm{~nm}$ with a Shimadzu ultraviolet spectrophotometer [7].

\section{Results and Discussion}

\subsection{Effect of the temperature on phenol degradation}

The effect of the temperature on the degradation of phenol was studied by the comparison of the results at $30^{\circ} \mathrm{C}$ and $40^{\circ} \mathrm{C}$ under the same operational conditions.

As shown on Figure 1, it is interesting to note that the bacterial growth is better at $40^{\circ} \mathrm{C}$, which is estimated at $112 \mathrm{mg} / \mathrm{l}$ after 96 hours, whereas at the temperature $30^{\circ} \mathrm{C}$, the bacterial mass was $70 \mathrm{mg} / \mathrm{l}$ after 97 hours. This result agrees with the theoretical data concerning the activity of Pseudomonas, which indicate an optimal temperature of growth between $30^{\circ} \mathrm{C}$ and $43^{\circ} \mathrm{C}$.

It is also found that the best degradation of phenol was observed at $30^{\circ} \mathrm{C}$ with a total degradation of phenol in 100 hours. At $40^{\circ} \mathrm{C}$ the time of the degradation was prolonged to 160 hours.

We can conclude that the $30^{\circ} \mathrm{C}$ temperature supports best the biological degradation of phenol by Pseudomonas aeruginosa.
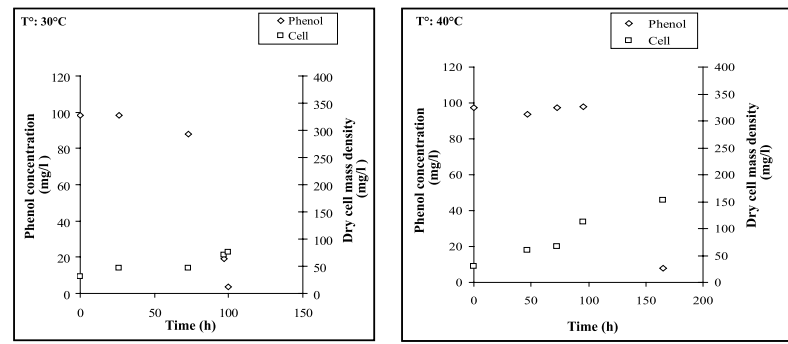

Figure 1. Effect of temperature on the bacterial growth and phenol biodegradation $[\mathrm{phenol}]_{0}=100 \mathrm{mg} / 1$, agitation $=78 \mathrm{rpm}$, Aeration $=0.24 \mathrm{1} /$ $\mathrm{mn}$, [Inoculum] $=414.36 \mathrm{mg} / 1$

\subsection{Effect of nature of the bacteria on phenol degradation}

To envisage the influence of the nature of the bacteria (revivified and no revivified) on the degradation of phenol, we carried out two experiments: the first with revivified bacteria (conserve during one week) and the second with no revivified bacteria (conserve during 6 months). Under the same operating conditions, and the same mineral media, the inoculum was added with a dry cell mass of $X=391.32 \mathrm{mg} / 1$. The bacterial growth and the degradation of phenol for the two tests are presented on the Figure 2.
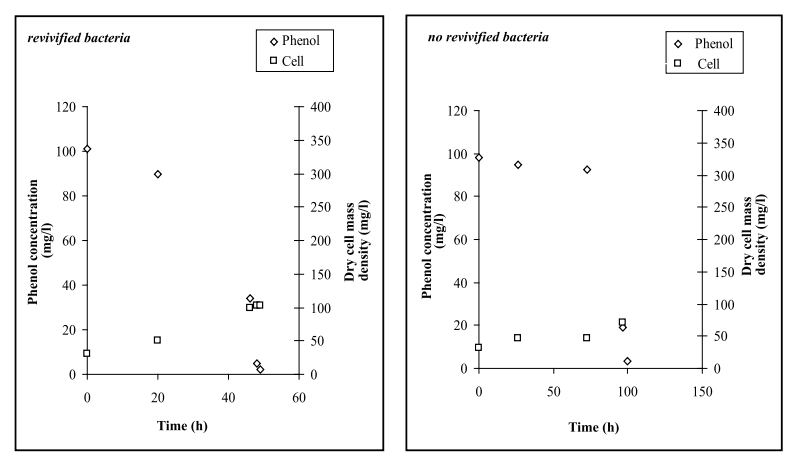

Figure 2. Effect of nature of bacteria on the bacterial growth and phenol biodegradation $[\mathrm{phenol}]_{0}=100 \mathrm{mg} / 1$, agitation $=78 \mathrm{rpm}$, Aeration $=$ $0.24 \mathrm{l} / \mathrm{mn}$, [Inoculum $]=495.67 \mathrm{mg} / \mathrm{l}, \mathrm{T}=30^{\circ} \mathrm{C}$

The first graphic shows a good bacterial growth $(100 \mathrm{mg} / 1$ after 48 hours) and a very fast degradation of phenol, the total degradation was observed at the end of the 49 hours. While for the no revivified bacteria, the cell multiplication was slowed down ( $70 \mathrm{mg} / \mathrm{l}$ after 100 hours); the degradation of phenol is started only after 72 hours.

From these results we can conclude that the regeneration of the bacterium allows its reactivation and the reproduction of its enzymatic activity. All these advantages of this reactive bacterial strain, has beloved their growth in the culture medium with a very great activity and a fast degradation of the phenol [8].

\subsection{Effect of adaptation of the bacteria on phenol degradation}

In the culture medium, the initial phenol concentration is $400 \mathrm{mg} / 1$ and the inoculums was added with a dry cell mass $281,75 \mathrm{mg} / 1$, keeping the same previously operating conditions, the results obtained for the bacterial growth and phenol degradation are presented on Figure 3a. 
According to the results (Figure 3a) we have noticed a very low bacterial growth that is due to the inhibiting effect of phenol at high concentrations. The presence of an excess of the phenol (the substrate) develops a saturation of the enzymatic sites charged by this last, which implies a reduction in its degradation.
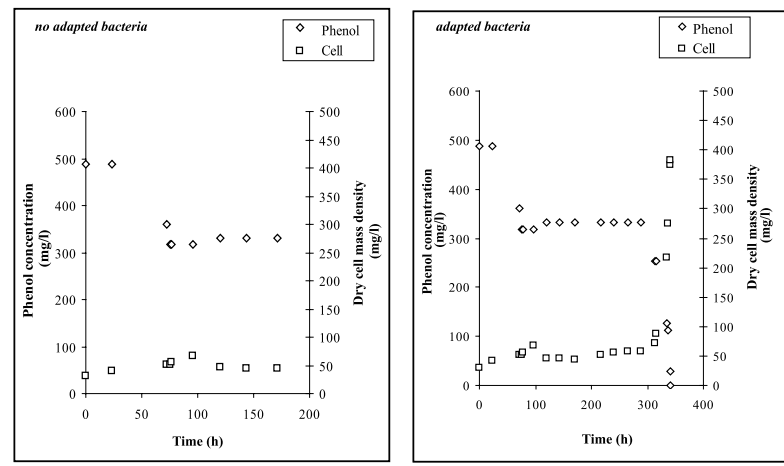

Figure 3. Effect of nature of bacteria on the bacterial growth and phenol biodegradation agitation $=78 \mathrm{rpm}$, Aeration $=0.241 / \mathrm{mn}, \mathrm{T}=30^{\circ} \mathrm{C}$

In this case the culture is not acclimated to the increasingly high levels of phenol experienced during the initial period of the shock loading and, consequently, we have obtained a partial degradation of phenol until a residual concentration of $300 \mathrm{mg} / \mathrm{l}$ and a decrease of the bacterial mass which corresponds to cellular lysis.

To test this point, the batch experiment was repeated with cells extracted directly from the effluent of a reactor operating in the same conditions with a low concentration of phenol $(100 \mathrm{mg} / \mathrm{l})$.

We have added to the medium $10 \mathrm{ml}$ of a medium, rich of bacteria after a degradation of $100 \mathrm{mg} / \mathrm{l}$ as explained before. The evolution of the concentration of phenol and the bacterial growth are presented on the (Figure 3b)

It is clear that the results are significantly different from those obtained with inoculums not acclimated to high levels of phenol.

From this result we can conclude that the adaptation of the bacteria to phenol is necessary for the survival of the biodegradation of the substrate in a medium with higher concentration of phenol. The enzymatic adaptation is defined like "the induced formation of an enzyme under the influence of its substrate" [9].

Pseudomonas aeruginosa adapted to phenol continued to develop and degrade phenol, and on the figure we observe a good growth of the bacterial mass which reaches $380 \mathrm{mg} / \mathrm{l}$ and a total degradation of phenol at the end of 170 hours.

\subsection{Factorial design methodology}

A factorial design $2^{2}$ method [10] was used to study the degradation of phenol from water. All the batch experiments are conducted with initial phenol concentration of $100 \mathrm{mg} / \mathrm{l}$ and $0.241 / \mathrm{mn}$ of aeration. The temperature and the bacteria size employed are shown in Table 1.

Table 1. High and low levels of factors.

\begin{tabular}{ccc}
\hline Factors & $\begin{array}{c}\text { Low level } \\
(-\mathbf{1})\end{array}$ & $\begin{array}{c}\text { High level } \\
(+\mathbf{1})\end{array}$ \\
\hline Temperature $\left({ }^{\circ} \mathrm{C}\right)\left(\mathbf{X}_{\mathbf{1}}\right)$ & 30 & 40 \\
The bacteria size $(\mathrm{mg} / \mathrm{l})\left(\mathbf{X}_{\mathbf{2}}\right)$ & 260.88 & 521.76 \\
\hline
\end{tabular}

A matrix was established according to their high and low levels, represented by +1 and -1 , respectively as given in Table 2 .

Table 2. Coded of the experimental design for the two variables.

\begin{tabular}{ccc}
\hline Experiment number & $\mathbf{X}_{\mathbf{1}}$ & $\mathbf{X}_{\mathbf{2}}$ \\
\hline 1 & -1 & -1 \\
2 & +1 & -1 \\
3 & -1 & +1 \\
4 & +1 & +1 \\
\hline
\end{tabular}

The result of each experiment is presented on the Figure 4; and the time of the degradation of phenol at each experiment is presented in Table 3.
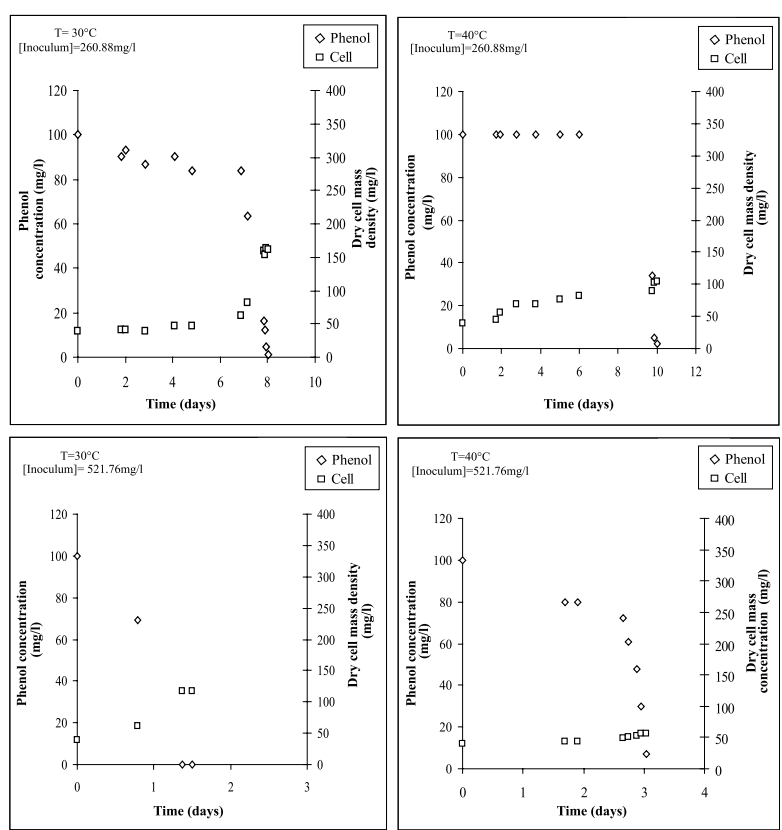

Figure 4. Evolution of bacterial growth and phenol concentration for the experimental design's experiments

Table 3. Experimental values for the time of the degradation of phenol by $P$. aeruginosa.

\begin{tabular}{ccccc}
\hline $\begin{array}{c}\mathbf{N}^{\circ} \text { of } \\
\text { Experiment }\end{array}$ & $\mathbf{X}_{\mathbf{1}}$ & $\mathbf{X}_{\mathbf{2}}$ & \multicolumn{2}{c}{ RESPONSE (Y) } \\
\hline 1 & -1 & -1 & $\mathrm{Y} 1$ & 8 \\
2 & +1 & -1 & $\mathrm{Y} 2$ & 10 \\
3 & -1 & +1 & $\mathrm{Y} 3$ & 1.5 \\
4 & +1 & +1 & $\mathrm{Y} 4$ & 3 \\
\hline
\end{tabular}

The codified mathematical model employed for $2^{2}$ factorial design without interaction was represented as follows:

$Y=a_{0}+a_{1} X_{1}+a_{2} X_{2}$

Where $\mathrm{Y}$ is the estimated response, a0 represents the global mean, and ai $(i=1,2)$ are the linear effects, $\mathrm{Xi}(\mathrm{i}=1,2)$ are the process variables.

Substituting the coefficients ai in the equation by their values the mathematical model selected will be the following: 


\section{$Y=5.625+0.875 X_{1}-3.375 X_{2}$}

The level of validity of the model is:

$30^{\circ} \mathrm{C}<$ Temperature $<40^{\circ} \mathrm{C}$

$260.88 \mathrm{mg} / 1<$ Bacteria size $<521.76 \mathrm{mg} / 1$

\section{Analyzes regression:}

The examination of the graphs of the regressions accompanying the model is based on the localization of each point experimental with its estimated value as indicated in the Table 4 and as presented in Figure 5.

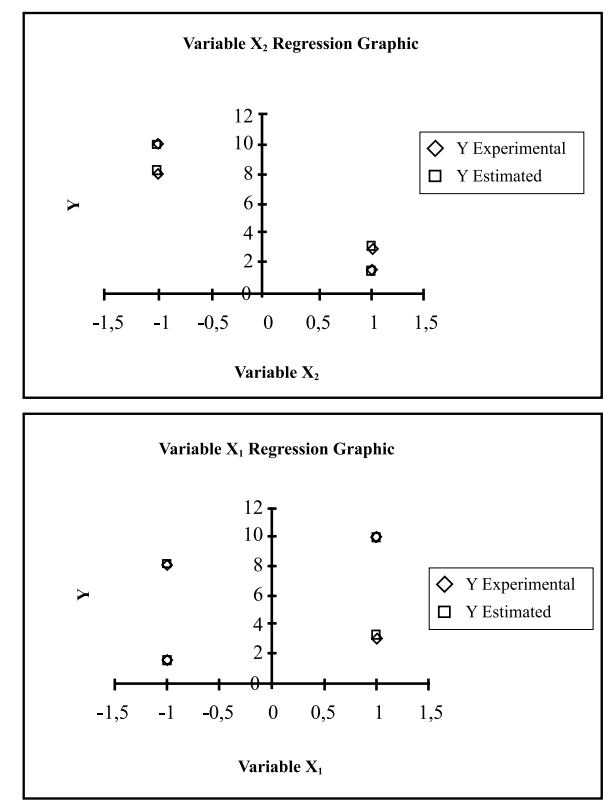

Figure 5. Comparison of the experimental and the estimated response at variable's levels

Table 4. Experimental and estimated response.

\begin{tabular}{cc}
\hline Y (experimental) & Y (estimated by the model) \\
\hline 8 & 8.125 \\
10 & 9.875 \\
1.5 & 1.375 \\
3 & 3.125 \\
\hline
\end{tabular}

The graphs show that the model suggested strongly approaches the studied phenomenon.

\section{Analysis of variance (ANOVA) [11]}

Regression analysis and ANOVA were used for examining the statistical significance of the model terms.

$F$-value is a statistically valid measure of how well the factors describe the variation of the data about the mean.

Student t-test was employed to determine whether calculated effects were significantly different from zero.

The $R^{2}$ coefficient gives the proportion of the total variation in the response predicted by the model. A high $R^{2}$ value, close to 1 , is desirable and a reasonable agreement with adjusted $R^{2}$ is necessary [12]. A high $R^{2}$ coefficient ensures a satisfactory adjustment of the model to the experimental data.

The analysis of variance (ANOVA) of the regression model and the determination of the $R^{2}$ coefficient demonstrates that the model is highly significant (Table 5).

Table 5. Regression analysis (ANOVA).

\begin{tabular}{ccccc}
\hline Source & $\begin{array}{c}\text { Sum of } \\
\text { squares }\end{array}$ & DF & $\begin{array}{c}\text { Mean } \\
\text { square }\end{array}$ & F-value \\
\hline Model & 48.625 & 2 & 24.312 & 389 \\
$\begin{array}{c}\text { Residual } \\
\text { (error) } \\
\text { Correlation } \\
\text { total }\end{array}$ & 0.0625 & 1 & 0.062 & \\
\hline $\mathbf{R}^{2}=\mathbf{0 . 9 9 8 7}$ & 48,6875 & 3 & & \\
\hline
\end{tabular}

The computed $F$-value was higher than the tabular value $\left(\mathrm{F}_{0.95,2,1}=200\right)$, it means that the linear effects $\left(\mathrm{X}_{1}\right.$ and $\left.\mathrm{X}_{2}\right)$ were significant.

The goodness of the modeling was evaluated by the determination of the coefficient $\left(R^{2}\right)$ and the adjusted determination coefficient $R_{A d j}^{2}$. In this case, $R^{2}=0.99872$ indicates that $99.87 \%$ of the variability in the response could be explained by the model. In addition, the value of $R_{A d j}^{2}$ was very high, indicating a high level of significance for the model. Moreover $R_{A d j}^{2}=0.9962$, which is very close to the $R^{2}$ value of 0.9987 , indicating that the model was accurate in describing the experimental data.

The Student's t-test employed is based on a simple hypothesis:

If $\mathrm{ti}>\mathrm{tc}$, the coefficient is significant, if not it is rejected from model.

$$
t_{i}=\frac{\left|a_{i}\right|}{s_{i}}
$$

ti: t-value calculated

tc: critical or tabular coefficient (t-tabular), is determined from the Student table with (n-p) freedom degrees and a 95\% confidence level.

$n$ : the number of experiments carried out, in our case $n=4$

$p$ : the number of coefficients of the model, for our study $p=3\left(a_{0}\right.$, $\left.\mathrm{a}_{1}, \mathrm{a}_{2}\right)$

The variance was calculated by using the following equations:

$$
s_{i}^{2}=\frac{s^{2}}{n}
$$

$s^{2}=\frac{1}{n-p} \cdot \sum e_{i}^{2}$ 
It was observed that for a $95 \%$ confidence level and one freedom degrees, the t-tabular was equal to 6.314 .

From the Table 6 , the condition $\mathrm{ti}>$ tc is checked; therefore the linear effect of the temperature and the bacteria size are significant.

Table 6. The corresponding t-value for the three coefficients.

\begin{tabular}{cc}
\hline Coefficient & t-value \\
\hline $\mathrm{a}_{0}$ & 45 \\
$\mathrm{a}_{1}$ & 7 \\
$\mathrm{a}_{2}$ & 27 \\
\hline
\end{tabular}

\section{Conclusion}

On the basis of the data, it is concluded that the temperature, the nature of bacteria, and the adaptation of bacteria to phenol can influenced directly on the bacterial growth and the degradation of phenol.

The factorial experimental design is a good technique for studying the influence of process parameters on response factors by significantly reducing the number of experiments.

First-order regression was developed for predicting the response, the experimental value agreed with the predicted value within a $95 \%$ confidence interval, suggesting a good fit between the models and the experimental data.

\section{References}

1. G. P. Prpich, A. J. Daugulis, Enhanced biodegradation of phenol by a microbial consortium in a solid-liquid two-phase partitioning bioreactor. Biodegradation 16, pp.329-339, (2005).

2. B. Usama, Abd-El-Haleem Desouky, M. Hassan, Z. Sahar, Phenol biodegradation by free and immobilized Acinetobacter. Biotechnol. Lett. 24, pp. 1295-1297, (2002).

3. Si-Jing Wang, Kai-Chee Loh, Modeling the role of metabolic intermediates in kinetics of phenol biodegradation. Enzyme and Microbial Technology, Vol. 25(3-5), pp. 177-184, (1999).

4. S. E. Agarry, B. O. Solomon, S. K. Layokun, Optimisation of process variables for the microbial degradation of phenol by Pseudomonas aeruginosa using response surface methodology. African Journal of Biotechnology, 7(14), pp. 2409-2416, (2008).

5. Y. Tao, Y. Wang, S. Yan and L. Ye, Optimization of omethoate degradation conditions and a kinetics model. International Biodeterioration \& Biodegradation, Vol. 62(3) pp. 239-243, doi:10.1016/j.biod.2008.01.014, (2008).

6. I. Banerjee, M. Jayant, K. Modak, K. Bandopadhyay, D. Das, B. R. Maiti, Mathematical model for evaluation of mass transfer limitations in phenol biodegradation by immobilized Pseudomonas putida, J. Biotechnol. 87, pp. 211-223, (2001).
7. APHA. Standard Methods for the examination of water and wastewater, American Public Health Association 20th edition, Washington, D.C., (1988).

8. J. P. Larpent, M. Larpent-Gourgaud, Microbiologie pratique, Hermann, Paris (1970).

9. J. Monod, Inducteurs et inhibiteurs spécifiques dans la biosynthèse d'un enzyme. La $\beta$-galactosidase d'Escherichia coli, Bulletin de l'Organisation mondiale de la santé, 6, pp. 59-64, Paris (1952).

10. J. Goupy, Introduction aux plans d'expériences, seconde Edition, Dunod, Paris (2001).

11. D. N. Gujarati, Econométrie, Traduction de la 4éme Edition Américaine par Bernard Bernier, (2004).

12. M. Y. Nordin, V. C. Venkatesh, S. Sharif, S. Elting, A. Abdullah, Application of response surface methodology in describing the performance of coated carbide tools when turning AISI 104 steel, Journal of Material Processing Technology, 145, pp.46-58, (2004). 